\title{
Pengetahuan Remaja Tentang Konsumsi Alkohol
}

\author{
Irma Darmawati ${ }^{1 *}$, Lita Nurlita ${ }^{2}$, Helwiyah Ropi ${ }^{3}$ \\ ${ }^{1}$ Fakultas Pendidikan Olahraga dan Kesehatan, Universitas Pendidikan Indonesia, \\ ${ }^{2}$ Rumah Sakit Dr. Hasan Sadikin Bandung, ${ }^{3}$ Fakultas Keperawatan, Universitas Padjadjaran \\ *Email: irmadarmawati@upi.edu
}

\begin{abstract}
Background: Alcohol misuse increase between adolescent. They are more concerned with peer's solidarity in drinking without being accompanied by a good knowledge. The aim of this study is to define adolescent's knowledge about alcohol consumption. Methods: A Cross Sectional study was conducted in 35 alcoholic adolescent respondents with 12-22 years age range. Results: Knowledge assesment result showed that $60 \%$ respondents had a lack of knowledge, and 100\% had negative attitudes and practices towards Alcohol consumption. Conclusion: Lack of knowledge related alcohol consumption in adolescents can spread to another risk behaviors in adolescents. Health workers should optimize the youth program such as PKPR in puskesmas by conducting health education especially on alcoholism and the long-term impact in the future.
\end{abstract}

Keywords: adolescent, alcohol consumption, knowledge

\section{PENDAHULUAN}

Penyalahgunaan minuman keras menyebabkan 1,8 juta kematian di seluruh dunia. Konsumsi alkohol bertanggung jawab terhadap lebih dari 55.000 kematian pada orang-orang yang berusia 15-29 tahun di Eropa (WHO, 2019). Alkohol merupakan penyebab kematian ketiga dalam kaitannya dengan berbagai komplikasi penyakit yang disebabkan oleh penyalahgunaan alkohol di Amerika (Herbert, Gilbert, Gonzalez-Izquierdo, Pitman, \& Li, 2015), sedangkan di Indonesia sendiri terdapat lebih dari 13.000 orang pasien yang menderita penyakit terkait penyalahgunaan alkohol, juga banyak lagi kasus yang kita temukan sehari hari di wilayah Indonesia, kematian akibat penyalahgunaan alkohol, 65 kematian karena keracunan alkohol, 40 kematian akibat keracunan alkohol dalam minuman keras oplosan, seperti di Surabaya (9 orang), Indramayu (11 orang), Papua (14 Orang), serta 10 orang meninggal akibat keracunan alkohol setelah menenggak sejumlah minuman keras di Kota Bandung.

Minuman keras adalah jenis NAZA (Narkotika, Alkohol, dan Zat adiktif) dalam bentuk minuman yang mengandung alkohol, tidak peduli berapa kadar alkohol di dalamnya. Minuman keras merupakan penekan (depressant) aktifitas susunan syaraf pusat, serta pada penggunaan yang kronis alkohol akan menyebabkan perubahan pada fungsi ion chanel (Hawari, 2012). Alkohol pun berpengaruh pada reseptor opioda dan pengaruh ini merupakan salah satu faktor penting mengapa alkohol dapat menyebabkan terjadinya ketergantungan.

Minuman keras sudah dikenal masyarakat Indonesia sejak dulu, bahkan beberapa etnik di Indonesia menggunakan minuman keras pada acara acara tertentu. Nama yang populer untuk berbagai minuman keras di Indonesia, misalnya : kamput, topi miring, cap tikus, balo, tuak, arak, dan ciu. (Hawari, 2012). Penyebaran minuman keras saat ini sudah sangat mewabah di masyarakat, tidak mengenal 
status ekonomi, sosial, maupun usia di berbagai belahan dunia, minuman keras merupakan masalah sosial tak hanya pada orang dewasa, tapi juga pada remaja yang merupakan periode peralihan antara masa kanak kanak dan masa dewasa.

Masa remaja merupakan periode peralihan antara masa anak dan dewasa, perubahan dalam hal biologis, intelektual, psikososial dan ekonomi (Wilson \& Rodgers, 2016). Masa remaja merupakan suatu bagian dari siklus tumbuh kembang sejak saat konsepsi sampai dewasa, dan merupakan suatu periode transisi dari masa anak-anak menjadi dewasa. Beberapa transisi yang dihadapi yaitu berupa transisi emosional, transisi dalam sosialisasi, transisi dalam agama, dan transisi dalam moralitas (Batubara, 2016). Dalam hal moralitas remaja, terdapat berbagai hal yang mempengaruhinya apakah remaja tersebut akan memiliki moralitas yang baik atau buruk. Moralitas yang buruk misalnya tercermin dalam perilaku meminum-minuman keras yang dilakukan oleh remaja, yang dalam hal ini dipengaruhi oleh faktor internal dan eksternal dari remaja tersebut (TannerSmith \& Lipsey, 2015).

Banyak

faktor

yang

melatarbelakangi remaja memutuskan untuk meminum-minuman keras. Seperti yang diungkapkan Tanner-Smith dan Lipsey (2015) bahwa pembentukan perilaku itu terkait dengan faktor internal diri remaja, seperti kepribadian dan pengetahuan, dan faktor eksternal dari luar diri remaja tersebut seperti lingkungan keluarga, masyarakat, dan teman sebaya. Pengetahuan adalah hasil dari tahu dan ini dapat terjadi pada setiap orang dari hasil penginderaannya terhadap objek tertentu. Pengetahuan dalam aspek kognitif merupakan domain yang sangat penting untuk terbentuknya tindakan seseorang. Seseorang akan berperilaku positif apabila didasari oleh pengetahuan, kesadaran dan sikap yang positif, dan sikap ini akan bertahan lama (Notoatmodjo, 2012). Kepribadian merupakan sifat yang berkaitan dengan karakteristik khusus yang ada pada orang perseorangan, berkaitan berkaitan dengan faktor biologis maupun psikologis. Kepribadian mewakili karakteristik individu yang terdiri dari pola-pola pikiran, perasaan dan perilaku yang konsisten (Minett, 2017).

Proses internalisasi dalam pembentukan kepribadian yang keliru lebih lanjut dapat memunculkan mekanisme pelarian diri dan pembelaan diri yang salah atau tidak rasional dalam wujud : kebiasaan agresif, pelanggaran terhadap norma baik sosial maupun hukum yang diwujudkan dalam bentuk kejahatan, kekerasan kebiasaan berkelahi massal dan sebagainya dan frutasi yang akhirnya di tampilkan secara spontan. Hal ini menunjukan bahwa keadaan psikologis remaja yang mengalami kegoncangan di bawah usia 22 tahun yang banyak melakukan kenakalan remaja, salah satunya perilaku minum-minuman keras (Tanner-Smith \& Lipsey, 2015).

Pengetahuan remaja menjadi dasar yang sangat penting dalam tahap tumbuh kembangnya (Darmawati \& Arumiyati, 2017). Hal ini dapat menentukan target dan tujuan hidup yang akan dilalui oleh remaja dimasa yang akan datang. Perilaku minum-minuman keras ini dapat menjadi gerbang bagi perilaku resiko lainnya yang mengancam kesehatan remaja. Penelitian ini dilakukan untuk mengetahui gambaran pengetahuan remaja tentang minuman keras pada kelompok peminum minuman keras. 


\section{METODE PENELITIAN}

Metode penelitian deskriptif kuantitatif digunakan untuk menggambarkan pengetahuan tentang konsumsi alkohol dengan pendekatan cross sectional. Teknik sampling yang digunakan adalah total sampling dengan kriteria utama termasuk dalam kategori usia remaja (12-22 tahun) dan memiliki perilaku minum minuman keras. Sejumlah 35 remaja yang mengonsumsi minuman keras berpartisipasi dalam penelitian ini. Penelitian dilakukan di wilayah Kelurahan Babakan Sari Kiaracondong Bandung.

Instrumen menggunakan pilihan ganda dengan 4 pilihan alternatif jawaban untuk mengukur pengetahuan. Skor benar

Tabel 1.Distribusi Frekuensi Karakteristik Responden

\begin{tabular}{|c|c|}
\hline Variabel & Total n (\%) \\
\hline \multicolumn{2}{|l|}{ Usia } \\
\hline 15-18 Tahun & $15(42,9)$ \\
\hline 19-22 Tahun & $20(57,1)$ \\
\hline \multicolumn{2}{|l|}{ Pendidikan } \\
\hline SD & $2(5,7)$ \\
\hline SMP & $17(48,6)$ \\
\hline SMA & $16(45,79)$ \\
\hline $\begin{array}{l}\text { Berdasarkan tabel diatas dapat } \\
\text { diinterpretasikan bahwa dari } 35 \\
\text { responden, } 42,9 \% \text { responden diantaranya } \\
\text { berada pada rentang usia } 15-18 \text { tahun, } \\
\text { yaitu sebanyak } 15 \text { orang dan } 57,1 \% \\
\text { responden berada pada rentang usia } 19-22 \\
\text { tahun, yaitu sebanyak } 20 \text { orang. 5,7\% } \\
\text { responden diantaranya lulusan SD, yakni } \\
\text { sebanyak } 2 \text { orang, } 48,6 \% \text { lulusan SMP, } \\
\text { yakni sebanyak } 17 \text { orang, serta } 45,79 \%\end{array}$ & $\begin{array}{l}\text { tingkat pendidikannnya SMA. Jumlah } \\
\text { responden lulusan SMP dan SMA hampir } \\
\text { setara, yang memaknakan bahwa setlah } \\
\text { lulus SMP ada remaja yang tidak } \\
\text { melanjutkan SMA namun ada juga yang } \\
\text { melanjutkan SMA pada kelompok dengan } \\
\text { rentang usia 19-22 tahun sebagai } \\
\text { kelompok usia terbanyak dalam penelitian } \\
\text { ini. }\end{array}$ \\
\hline \multicolumn{2}{|c|}{ Tabel 2. Distribusi Frekuensi Tingkat Pengetahuan Responden } \\
\hline Tingkat Pengetahuan & Total n (\%) \\
\hline Baik & $6(17)$ \\
\hline Cukup & $8(23)$ \\
\hline Kurang & $21(60)$ \\
\hline Total & $35(100)$ \\
\hline
\end{tabular}

diberikan nilai 1 dan salah diberikan nilai 0 . Jenis pertanyaan yang digunakan adalah pertanyaan tertutup. Hasil uji validitas, nilai koefisien korelasi adalah $\geq$ 0,3 dan hasil uji reliabilitas instrumen menunjukkan nilai $\alpha$ sebesar 1,017 .

\section{HASIL PENELITIAN}

Hasil penelitian ini dijelaskan secara deskriptif pada gambaran demografi dan gambaran pengetahuan remaja peminumminuman keras di wilayah Babakan Sari Kota Bandung. Pengetahuan dikelompokan menjadi kriteria baik, cukup, dan kurang. 
Dari tabel 2 tersebut diketahui bahwa sebanyak $17 \%$ memiliki pengetahuan yang baik, $23 \%$ memilki pengetahuan cukup, dan $60 \%$ dari responden memiliki tingkat pengetahuan yang kurang mengenai minuman keras. Pengkategorian tingkat pengetahuan dikelompokan berdasarkan penilaian baik (76\%-100\%), cukup (56\%-75\%), dan kurang $(<=55 \%)$.

Tabel 3. Analisis Item Pertanyaaan Pengetahuan Responden

\begin{tabular}{lll}
\hline \multicolumn{1}{c}{$\mathbf{Z}$} & Benar & Salah \\
\hline Definisi minuman keras & $62.9 \%$ & $37.1 \%$ \\
Zat adiktif dalam minuman keras & $62.9 \%$ & $37.1 \%$ \\
Tanda mabuk & $62.9 \%$ & $37.1 \%$ \\
Fakta minuman keras & $34.3 \%$ & $65.7 \%$ \\
Kematian akibat alkohol & $48.6 \%$ & $51.4 \%$ \\
Minuman oplosan & $62.9 \%$ & $37.1 \%$ \\
Zat berbahaya dalam minuman oplosan & $48.6 \%$ & $51.4 \%$ \\
Gangguan Kesehatan akibat minuman keras & $54.3 \%$ & $45.7 \%$ \\
Perubahan perasaan saat mabuk & $51.4 \%$ & $48.6 \%$ \\
Bahan minuman oplosan & $62.9 \%$ & $37.1 \%$ \\
\hline
\end{tabular}

Dari Tabel 3 tersebut presentase tertinggi responden menjawab benar adalah pada 5 item pertanyaan, mengenai pengertian minuman keras, kandungan zat adiktif, tanda-tanda mabuk, akibat buruk dari menenggak minuman keras oplosan, serta bahan pencampur yang biasa digunakan dalam minuman keras oplosan, yakni sebesar $62,9 \%$ atau sejumlah 22 responden.

\section{PEMBAHASAN}

Berdasarkan hasil distribusi frekuensi pada karakteristik responden diperoleh gambaran karakteristik responden sebagai berikut, dalam hasil penelitian ini terlihat lebih besar kecenderungan remaja berperilaku minum-minuman keras pada rentang usia 19-22 tahun yang merupakan masa remaja akhir, yaitu sebesar (57\%), masa ini merupakan ambang masa dewasa.

Semakin mendekatnya usia kematangan, para remaja menjadi gelisah untuk meninggalkan stereotip selama belasan tahun dan untuk memberikan kesan bahwa mereka sudah hampir dewasa. Berpakaian dan bertindak seperti orang dewasa belum cukup, sehingga mereka mulai memusatkan diri pada perilaku yang dihubungkan dengan status dewasa, yaitu merokok, minum-minuman keras, menggunakan obat-obatan terlarang, dan terlibat dalam perbuatan seks (Wilson \& Rodgers, 2016). Usia dapat berpengaruh terhadap kecerdasan emosional seseorang (Yuniar \& Darmawati, 2017). Mereka menganggap perbuatan tersebut akan memberikan citra sesuai yang mereka inginkan. Tingkat kematangan seseorang akan bertambah ketika usia bertambah (Darmawan, R., \& Sudiro, S, 2020).

Pada masa ini para remaja sering menganggap diri mereka serba mampu, sehingga seringkali mereka terlihat tidak memikirkan akibat dari perbuatan mereka. Tindakan impulsif sering dilakukan, sebagian karena mereka tidak sadar dan belum biasa memperhitungkan akibat jangka pendek atau jangka panjang (Batubara, 2016). Oleh karena itu, pada 
masa ini, remaja sangat rentan terhadap perilaku yang menyimpang seperti halnya perilaku minum-minuman keras.

Berdasarkan tingkat pendidikan hampir setengahnya responden adalah lulusan SMP yakni sebesar 48,6\%. Tingkat pendidikan seseorang menentukan bagaimana cara dia berfikir dalam menentukan keputusan dan menghadapi masalah. Semakin tinggi tingkat pendidikan seseorang diharapkan semakin meningkat tingkat kedewasaan yang dimiliki (Notoatmodjo, 2012). Pembinaan moral yang nyata dari pendidik di sekolah menjadi faktor kunci dalam proses perkembangan kepribadian remaja.

Dari penelitian ini responden yang berperilaku minum-minuman keras hampir setengahnya berasal dari tingkat pendidikan SMP, tingkat pendidikan ini berpengaruh pada proses kedewasaan serta proses pengambilan keputusannya dalam berperilaku, remaja yang tidak melanjutkan sekolah ke tingkat selanjutnya ini kurang mendapat contoh moral yang kuat, yang ditanamkan sekolah secara berkala dan berkesinambungan, remaja ini pun kurang dapat berfikir panjang akan perilaku yang akan dilakukannya, serta ada pula kemungkinan remaja kurang mendapatkan berbagai wawasan atau pengetahuan mengenai berbagai hal yang harus dijauhi oleh remaja pada masa perkembangannya.

Dari penelitian ini didapatkan hasil bahwa tingkat pengetahuan responden baik pada 17 orang responden, namun tingkat pengetahuan kurang pada sebagian besar $(60 \%)$ responden. Pengetahuan adalah sesuatu yang diketahui atau kepandaian yang dimiliki seseorang melalui pendidikan maupun pengalaman (Notoatmodjo, 2012). Pengetahuan yang dimiliki responden ini, bisa jadi responden dapatkan dari sekolah tempat responden belajar, media-media informasi, ataupun melalui pengalaman yang dimilikinya terkait dengan konsumsi minuman keras.

Pada item pertanyaan yang rata-rata diketahui oleh sebagian besar responden adalah untuk item pengertian minuman keras, kandungan zat adiktif dalam minuman keras, tanda-tanda mabuk, akibat buruk dari menenggak minuman keras oplosan, serta bahan pencampur yang biasa digunakan dalam minuman keras oplosan, sedangkan item yang paling banyak tidak diketahui oleh responden adalah item mengenai faktafakta yang benar mengenai minuman keras, dampak minuman keras oplosan terhadap tubuh, serta kandungan yang terdapat dalam minuman keras oplosan. Secara keseluruhan, pengetahuan responden dalam penelitian ini adalah kurang.

Untuk item pertanyaan dasar mengenai pengertian minuman keras itu sendiri misalnya, walaupun item ini merupakan item yang prosentase terjawabnya sebesar $62,9 \%$, namun terdapat hampir setengahnya dari responden yang tidak mengetahui apa yang mereka minum pada hakikatnya, pengetahuan mereka tentang minuman keras ini masih banyak yang menganggap minuman keras sebagai minuman jamu tradisional khas daerah, ataupun minuman keras sebagai obat kuat untuk meningkatkan stamina, hampir setengahnya dari responden ini tidak mengetahui pengertian dari minuman keras itu sendiri, malah justru menganggap minuman keras sebagai suatu hal yang baik, dan berpandangan tidak ada salahnya untuk diminum. Selanjutnya untuk item kedua yang paling banyak 
menjawab benar pun, terdapat hampir setengahnya dari responden, yakni sebesar $37,1 \%$ yang tidak mengetahui bahwa minuman keras yang mereka minum itu merupakan zat adiktif yang akan mengakibatkan efek ketagihan untuk menambah dosis dan potensi ketergantungan terhadap minuman keras akibat dari sifat minuman keras itu sendiri.

Item pertanyaan selanjutnya yakni mengenai tanda-tanda mabuk akibat minum-minuman keras, sebesar 62,9\% responden mengetahui tanda-tanda mabuk berupa bicara tidak jelas, jalan sempoyongan, mual dan muntah, sementara $37,1 \%$ sisanya tidak mengetahui yang dimaksud dengan tandatanda mabuk, atau kemungkinan responden terkecoh dengan item jawaban selera makan meningkat, dikaitkan dengan efek kuat yang dibayangkan mereka dengan meminum minuman keras. Meskipun sebagian besar dari responden mengetahui tanda-tanda mabuk, namun terdapat nilai prosentase yang berbeda dengan pertanyaan mengenai perubahan perasaan yang dialami ketika mabuk, dengan perbedaan prosentase senilai $11,5 \%$.

Item pertanyaan selanjutnya mengenai pernyataan yang salah mengenai minuman keras, merupakan item yang paling sedikit diketahui oleh responden, hanya mencapai 34,3\% responden yang mengetahui secara pasti pernyataan yang salah mengenai minuman keras, seperti kita akan sulit mengendalikan minum-minuman keras bila sudah ketagihan, minuman keras tidak mengandung vitamin apapun, minuman keras dapat memperburuk penyakit, mempercepat kematian, serta menurunkan kesehatan fisik dan mental. Dalam hal ini, terkait faktor frame of thinking responden bahwa minuman keras itu tidak terlalu berbahaya, dan malah dapat meningkatkan kekuatan, serta menyehatkan badan, terbukti dengan banyaknya responden yang tidak memilih pilihan jawaban anggur kolesom berkhasiat menyehatkan badan, yang sebenarnya merupakan pernyataan yang salah mengenai minuman keras.

Item pertanyaan selanjutnya membahas mengenai kematian yang diakibatkan minuman keras oplosan, yang diakibatkan karena adanya proses keracunan akut pada tubuh peminumminuman keras, hanya $48,5 \%$ responden yang mengetahui penyebab kematian pada peminum-minuman keras oplosan. Item pertanyaan selanjutnya masih membahas mengenai minuman keras oplosan terkait dengan kandungan minuman keras oplosan yang tidak jelas kadar alkohol yang digunakan, responden yang mengetahui item pertanyaan ini adalah sebanyak $62,9 \%$, yakni sekitar 22 responden, sedangkan untuk 13 responden lainnya tidak mengetahui mengapa minuman keras oplosan tersebut berbahaya untuk diminum karena kadar alkoholnya yang tidak jelas.

Begitupula dengan item pertanyaan selanjutnya, hampir setengah dari responden, yakni sebanyak 48,6\% tidak mengetahui zat berbahaya yang terkandung dalam minuman keras oplosan berupa alkohol industri yang biasa digunakan untuk membunuh kuman, namun untuk item pertanyaan terakhir mengenai contoh zat campuran yang dicampur dalam minuman keras oplosan, sebagian besar responden mengetahui jenis alkohol yang digunakan sebagai bahan campuran yakni spirtus, terdapat perbedaan jawaban yang cukup signifikan 
pada jawaban responden sekitar 14,3\% untuk jawaban zat berbahaya yang terdapat dalam minuman keras oplosan berupa alkohol untuk industri yang salah satu contohnya adalah spirtus, perbedaan jawaban yang terjadi kemungkinan disebabkan perbedaan persepsi mengenai spirtus yang merupakan salah satu contoh alkohol untuk membunuh kuman yang didasari pula pada hakikatnya akan pengetahuan mereka yang kurang mengenai minuman keras.

Dari hasil penelitian pada 35 responden ini, didapatkan hasil yang kurang akan pengetahuan remaja di kawasan Kelurahan Babakan Sari mengenai minuman keras. Responden dalam penelitian ini sendiri bahkan tidak mengetahui bahaya yang mengintai mereka akibat dari pengetahuan atau wawasan yang kurang mengenai minuman keras, maka bisa dikatakan suatu hal yang wajar bila mereka masih tetap minumminuman keras, dan bisa jadi merupakan hal yang sulit untuk mengubah kebiasaan minum-minuman keras bila tidak didasari domain kognitif, pengetahuan yang kuat pada masing-masing individu, seperti yang diuraikan dalam Notoatmodjo (2012), bahwa terbentuknya suatu perilaku baru, terutama remaja dimulai pada domain kognitif, dalam arti subjek tahu terlebih dahulu terhadap stimulus yang berupa materi atau objek diluarnya. Sehingga menimbulkan pengetahuan baru pada subjek tersebut, yang kemudian menimbulkan respon batin dalam bentuk sikap subjek terhadap objek yang diketahuinya. Apabila penerimaan perilaku baru atau adopsi perilaku melalui proses seperti ini didasari oleh pengetahuan, kesadaran dan sikap yang positif, maka perilaku tersebut akan langgeng (long lasting). Sebaliknya apabila perilaku ini tidak didasari oleh pengetahuan dan sikap yang positif maka tidak akan berlangsung lama.

Hal ini dapat kita artikan bahwa perilaku minum-minuman keras pada remaja di Kelurahan Babakan Sari yang didasari kurangnya pengetahuan ini, bisa jadi menimbulkan perubahan perilaku untuk tidak minum-minuman keras setelah mereka dipapakan pengetahuan mengenai minuman keras yang kerap mereka konsumsi, sebelum orang mengadopsi perilaku baru (berperilaku baru), di dalam diri orang tersebut terjadi proses yang berurutan yakni: Awareness (kesadaran), yakni orang tersebut menyadari dalam arti mengetahui stimulus (objek) terlebih dahulu dalam hal ini mengenai minuman keras itu sendiri, interest, yakni orang mulai tertarik kepada stimulus, evaluation, (menimbang-nimbang baik dan tidaknya stimulus tersebut bagi dirinya), memikirkan dampak positif dan negatif minuman keras terhadap dirinya.

Hal ini berarti sikap responden sudah lebih baik lagi. Selanjutnya trial, orang telah mulai mencoba perilaku baru, baik untuk minum-minuman keras ataupun justru untuk berubah tidak minum-minuman keras kembali, lalu adoption, subjek telah berperilaku baru sesuai dengan pengetahuan, kesadaran, dan sikapnya terhadap stimulus. Dengan bertambahnya pengetahuan, menumbuhkan sikap yang positif untuk tidak mengkonsumsi kembali minuman keras, dan hal ini menurut Notoatmodjo akan bertahan lama, langgeng, karena perilakunya didasari oleh pengetahuan, kesadaran, dan sikap positif untuk tidak mengkonsumsi minuman keras. 


\section{KESIMPULAN DAN SARAN}

Pengetahuan remaja terkait konsumsi alkohol ini kurang pada sebagian besar responden. Remaja berperilaku minum-minuman keras tanpa disertai pengetahuan yang baik terkait konsumsi alkohol serta bahaya yang akan dihadapi di masa yang akan datang

Petugas kesehatan diharapkan dapat merencanakan program sebagai upaya pencegahan perkembangan fenomena minum-minuman keras di kalangan remaja. Perencanaan program dapat berupa kegiatan penyuluhan mengenai dampak negatif minuman keras, advokasi penegakan aturan dan sanksi yang jelas bagi peminum-minuman keras, serta utamanya pada produktivitas remaja dalam pemanfaatan waktu luang tanpa aktifitas negatif seperti minum-minuman keras.

\section{DAFTAR RUJUKAN}

Batubara, J. R. L. (2016). Adolescent development (perkembangan remaja). Sari Pediatri, 12(1), 21-29.

Darmawan, R., \& Sudiro, S. (2020). Pengalaman Keluarga dalam Perawatan Pasien Skizofrenia Berdasarkan Kebijakan Kesehatan Mental Berbasis Komunitas. Caring : Jurnal Keperawatan,9(1), 9-15. https://doi.org/10.29238/caring.v9i1. 568

Darmawati, I., \& Arumiyati, S. (2017). Pengetahuan Gizi Remaja SMPN 40 Kota Bandung. Jurnal Kesehatan, 10(2), 49-57.

Hawari, D. (2012). Panduan Rehabilitasi
Gangguan Mental dan Perilaku Akibat Miras, Narkoba dan Penderita Skizofrenia. Bandung: Juli.

Herbert, A., Gilbert, R., GonzalezIzquierdo, A., Pitman, A., \& Li, L. (2015). 10-y risks of death and emergency re-admission in adolescents hospitalised with violent, drug-or alcohol-related, or selfinflicted injury: a population-based cohort study. PLoS Medicine, 12(12), e1001931.

Minett, P. (2017). Child Care and Development 7th Edition. Hodder Education.

Notoatmodjo, S. (2012). Promosi kesehatan dan perilaku kesehatan. Jakarta: Rineka Cipta, 45-62.

Tanner-Smith, E. E., \& Lipsey, M. W. (2015). Brief alcohol interventions for adolescents and young adults: A systematic review and meta-analysis. Journal of Substance Abuse Treatment, 51, 1-18.

WHO. (2019). Global status report on alcohol and health 2018. World Health Organization.

Wilson, D., \& Rodgers, C. C. (2016). Wong's essentials of pediatric nursing-e-book. Elsevier Health Sciences.

Yuniar, D., \& Darmawati, I. (2017). Dukungan Keluarga Berhubungan Dengan Kecerdasan Emosional Remaja. Jurnal Keperawatan Komprehensif (Comprehensive Nursing Journal), 3(1), 9-17. 